\title{
Relativizm ve Pazarlama Bilimine Etkileri
}

\section{Relativism and Its Effects on Marketing Science}

\section{Murat ÖZ}

Doç. Dr., Karamanoğlu Mehmetbey Üniversitesi

muratoz@kmu.edu.tr

https://orcid.org/0000-0003-4955-3848

\section{Kemal KAMACI}

$\ddot{O} \breve{g r}$. Gör., Karamanoğlu Mehmetbey Üniversitesi

kemalkamaci@kmu.edu.tr

https://orcid.org/0000-0003-4234-674X
Makale Başvuru Tarihi / Received: 08.11.2021

Makale Kabul Tarihi / Accepted: 24.11.2021

Makale Türü / Article Type: Derleme Makalesi
Anahtar

Kelimeler:

Relativizm,

Postmodernizm,

Postmodern

Pazarlama

Keywords:

Relativism

Postmodernism,

Postmodern

Marketing

\section{ÖZET}

Dünyadaki hiçbir olgunun stabil olmadiğg görüșünü savunan relativist düșünce, pazarlama anlayıșında paradigmal değișimlere yol açarak pazarlama biliminin epistemolojik temelde yeniden yapılandırlmasına neden olmuștur. Relativist düșüncenin etkisiyle olușan kișiye görelilik hayatın her alanına etki etmiş, toplumların ve insanların tüketim kalıplarıyla birlikte hayat tarzlarını da değişmiştir. Küresel ve teknolojik gelişmelerle birlikte yaşanan bu değişim ve gelişimin bir sonucu olarak pazarlama biliminde modern pazarlama ilkeleri eleştirilmeye başlanmış ve postmodern bir pazarlama anlayışı benimsenmiştir. Postmodernist anlayış da tüketici profilinde radikal değişimlerin yaşanmasını sağlamış, ayrıca işletmelerin de yerellikten küresele doğru bir dönüșüm içerisine girme sürecini bașlatmıștır. Çalıșmada relativist düșüncenin pazarlama bilimine etkisi, pazarlamanın dönemsel evrimiyle birlikte ele alınarak pazarlama anlayışında meydana getirdiği değişimlere değinilmiştir.

\section{ABSTRACT}

Relativist thought, which advocates the view that no phenomenon in the world is stable, has led to paradigm shifts in the understanding of marketing and has led to the restructuring of marketing science on an epistemological basis. Relativity to the person, formed by the influence of relativist thought, has affected all areas of life, and lifestyles have changed along with the consumption patterns of societies and people. As a result of this change and development experienced with global and technological growth, modern marketing principles have been criticized in marketing science and a postmodern marketing understanding has been adopted. The postmodernist understanding has also led to radical changes in the consumer profile and has also started the process of transforming businesses from local to global. In the study, the effect of relativist thought on marketing science was discussed together with the periodic evolution of marketing, and the changes in the understanding of marketing were mentioned. 


\section{GİRIŞ}

Son y1llarda yaşanan küresel ve teknolojik gelişmelerle birlikte artarak değişen tüketici ihtiyaç ve beklentileri pazarlama bilimini de doğrudan etkileyerek postmodernist bir pazarlama anlayışının ortaya çıkmasına neden olmuştur. Yaşanan değişim ve gelişimin bir sonucu olarak modern pazarlama ilkelerinin eleştirel bir bakış açısı olan postmodernist anlayış da, tüketici profilinde radikal değişimlerin yaşanmasına ayrıca işletmelerin de yerellikten küresele doğru bir dönüşüm içerisine girme sürecini başlatmıştır. Tüm dünya bir pazar yeri olmuş ve pazarlama anlamında da dünyada sınırların eridiği bir dönem başlamıştır. Relativist düşüncenin etkisiyle oluşan kişiye görelilik hayatın her alanına etki etmiş, toplumların ve insanların tüketim kalıpları ile hayat tarzları değişmiştir. Benzer ürünler küçük farklılıklarla ayrı ayrı talep edilmiş, sıradanlık kalkmış özgünlük ise öne çıkmıştır. Bu durum mikro pazarların oluşmasına, daha küçük ölçeklerde mal ve hizmetlerin tasarlanıp pazara sunulmasına yol açmıştır. Postmodern dönemde işletmelerin temel amacı ise bu faaliyetlerle müşteriyi, toplumu ve çevreyi tatmin ederek uzun vadede varlıklarını sürdürmek olmuştur.

\section{RELATIVIST DÜŞÜNCE (RELATIVIZM)}

Felsefenin temelinin İ.Ö. 6. yy’da Greklere dayandığı düşünülmekte ve iki döneme ayrılmaktadır; ilk dönemde metafiziğe, matematiğe ve senteze daha çok önem verilirken ikinci dönemde eleştiriye, analize ve bilime daha çok yer verildiği görülmektedir (Taşçıer, 2001:2-3). İkinci dönem olarak ifade edilen eleştirel düşünce devri, Protogoras'ın ünlü sözü; 'İnsan her şeyin ölçüsüdür; var olan şeylerin var olduklarının ve var olmayan şeylerin var olmadıklarının' görüşünü savunan relativist doktrini ile başlamış ve bu söz değerlere yönelik relativizmin ortaya çıkmasına neden olmuştur (Ergül, 2007:61; Taş̧̧ıer, 2001:7). Bu, herkes için geçerli bir bilginin olamayacağını bildiren yargıyı da ifade etmektedir. Bu görüşe göre gerçeklik ve değer yargıları toplumlara ve hatta her bir insana göre değişiklik göstermektedir.

Relativizm yeni bir yaklaşım olmayıp felsefe tarihinde sürekli gündemde kalmış olan bir yönelim biçimi olarak da tanımlanmaktadır (Muncy ve Fisk, 1987:23). Relativist bakış açısına göre 'gerçeklik' bir yapıdır ve belirli bir bağlamda özel bir inanç türünü ifade etmek için tasarlanmış bir kavramdır. Bir meselenin doğru olması onu benimsemiş birinin öznel inancını ifade etmektedir. Daha genel bir ifadeyle, relativist düşünceye göre dünyada hiçbir şey insanoğlunun duygularından, algılamalardan ve eylemlerden bağımsız olarak yorumlanamaz, bütün bilgilerin 'göreli' olduğu önermesi bu düşüncenin başlica argümanı olmuştur (Peter, 1992:72).

Relativizmin değerlendirilmesinde, ilk ve belki de en önemli soru 'Relativizm nedir?' sorusudur. Relativizm, çeşitli yorumlara sahip bir doktrin olup terim olarak duyguların şaşırtıcı çeşitliliğini ifade etmektedir (Boghossian, 2006:14). Relativizm, basit bir ifadeyle bir şeyin başka bir şeye bağlı olduğu fikirdir ve 'gerçeklik (truth)' kavramını reddetmez, genelde 'mutlak gerçeklik' kavramını 'göreceli gerçeklik' kavramıyla değiştirir. Relativizm bu haliyle, gerçeklikle ilgili her bir değerlendirmenin, ortaya atıldığ 1 tarihsel dönemdeki kültürel, dilbilimsel ve teknik durumlarla bağlantılı olarak yapılmasını ön görmektedir. Çünkü relativizm, her bir nesneyi adlandırma ile anlamlandırma bakımından diller ve kültürler arasında belirgin farklılıkların olduğunu varsaymaktadır (Peter, 1992).

\section{RELATIVIZM VE PAZARLAMANIN POSTMODERN YÖNELIMI}

20. yüzyıl, toplumlarda, teknolojide ve kavramsal şekiller arasında büyük değişimlerin yaşandığı bir dönem olmuştur. Bu durum da relativist düşüncenin verimli bir şekilde gelişmesine zemin hazırlamıştır. Bunun sonucu olarak son 30-40 yılda relativist düşünce önemli gelişmeler katetmiştir. Relativizm, kolay anlaşılabilir felsefi bir doktrin olmasa ve uygulama aşamaları da çok çeşitli ve karmaşı olsa da pazarlama biliminin epistemolojik temellerine etkisinden dolayı üzerinde durulması gereken bir husus olarak karşımıza çıkmaktadır (Muncy ve Fisk, 1987).

Herhangi bir şeyin bir başka şeye karşı göreli olma durumu olarak da ifade edilen relativizmin en temel hali; bireye, topluma veya herhangi bir duruma bağlı olarak değişebilen ahlaki görecelik kavramıyla ortaya çıkmış olsa da relativizmin bilişsel yönü pazarlama bilimini daha yakından ilgilendirmektedir (Tiltay, 2013:6). Buna göre pazarlama kavramı pazarlamanın yaşadığı dönüşümlere göre farklı şekillerde tanımlanmıştır.

Pazarlamanın ilk dönemi ürün odaklı pazarlama anlayışının hâkim olduğu dönemdir. Fordist üretim sisteminin etkilerinin görüldüğ̈̈ bu dönemde işletmelerde "ne üretirsem onu satarım" düşüncesi benimsenmiştir. Üretim odaklı işletmelerin olduğu bu dönemin öne çıkan özelliği, işletmelerin müşteri ile ilgili hiçbir bilgiyi değerlendirmeden ve ürünü satma gayreti içerisine girmeden sadece üretim yaparak müşterilerin satın almasını beklemeleridir (Alabay, 2010:217). Bu dönemde tüketiciler sınırlı sayıdaki üreticiden ihtiyaçlarını karşılamak zorunda olduklarından pazarlamada, müşteri ihtiyaçları veya müşteri beklentileri gibi unsurlar dikkate alınmamıştır. Ürün odaklı pazarlama anlayışının benimsendiği ve küresel ekonominin dengesini değiştiren Büyük 
Ekonomik Kriz'in başlangıcına kadar devam eden bu evrede, pazarlama birimi de departman olarak işletmelerde yer bulmamıştır (Mucuk, 2001:8). Pazarlama ile ilgili resmi bir tanım geliştirme çabaları da bu dönemde başlamıştır. Pazarlama karması paradigmasının en önemli savunucusu durumunda olan Amerikan Pazarlama Birliği (Amerikan Marketing Association-AMA) 1935 yılından itibaren çeşitli dönemlerde güncel pazarlama tanımları geliştirmiştir. Buna göre AMA tarafindan 1935 yılında yapılan ilk tanımda pazarlama; "Üreticiden tüketiciye doğru, malların ve hizmetlerin akışını sağlayan işletme faaliyetleridir." şeklinde tanımlanmıştır (Gedik, 2020:26).

Küresel olarak yaşanan Büyük Ekonomik Krizle birlikte pazarlamada 'satış odaklı pazarlama anlayışı' dönemi başlamıştır. Bu dönemde krizin de etkisiyle işletmeler ürettikleri malları satmakta sorunlar yaşamaya başlamışlar ve rekabet kavramıyla tanışmışlardır (Tekin, Şahin ve Göbenez, 2014:226). Tutundurma faaliyetlerinin gerekliliğini fark eden işletmeler ürünlerini satabilmek için etkili tanıtım çalışmaları içerisine girmişlerdir. İşletmelerde pazarlama bölümlerinin de yer almaya başladığı bu evrede satış artırmaya yönelik faaliyetler ve bu faaliyetleri yönetenler işletme yönetiminin ön saflarında kendilerine yer bulmuşlardır (Sommers, 1998:7-8). 'Üretimin önceliği' anlayışının yerini 'kâr sağlayacak satış' anlayışına bıraktığı ve geleneksel pazarlama anlayışının hâkim olduğu dönem olarak da bilinen bu evrede, işletmelerin temel hedefi daha çok kişiye satış yaparak kârı maksimize etmek olmuştur. Bundan dolayıdır ki, müşterilerin tutumları, ihtiyaçları, beklentileri ve hatta satın alma geçmişi işletmeler tarafından daha çok dikkate alınır hale gelmiştir (Bayuk, 2005:30).

Müşteri ve tüketici unsurunun işletmelerin pazarda varlıklarını sürdürebilmeleri için üzerinde durulması gereken konular olarak görülmeye, tüketici ihtiyaç, tutum ve beklentilerinin dikkate alınmaya başlandığı "Pazar-Tüketici Odaklı Pazarlama Anlayışı Dönemi” pazarlamanın üçüncü evresi olarak tanımlanmaktadır. Tüketici kavramının pazarlamanın odak noktasını oluşturduğu bu dönemde, çalışanlar ile müşteriler arasında koordinasyon ve işbirliğini artırmayı hedefleyen yöntemler geliştirilmeye başlanmış ve işletmeler arasında müşterilere daha iyi nasıl hizmet veririm rekabeti yaşanmıştır. Ürün ve hizmette kalite anlayışının odak noktaya oturtulduğu, koşulsuz şartsız müşteri memnuniyetinin sağlanmaya çalışıldığı bu dönemde kalitesizlik ise bir maliyet olarak görülmüştür. Burada temel amaç ise müşteri tatmini yoluyla kârı maksimize etmek olmuştur (Mucuk, 2001:9-10). Bu doğrultuda işletmeler 1970'lerde ürün/hizmet çeşitlendirmelerine gitmişler, 1980'li y1llarda ise müşteriler gruplara ayrılmış her bir müşterilerin tutum, davranış, hayat anlayışı, satın alma alışkanlıklarına göre pazarlama stratejileri geliştirilerek modern pazarlama anlayışı uygulanmaya başlanmıştır (Bozkurt, 2014). Pazarlamanın ikinci evresinden farklı olarak işletmeler tüketicileri ürettikleri mal ve hizmetleri satın almaya ikna etmek yerine, tam olarak müşterilerin istek ve ihtiyaçları doğrultusunda mal ve hizmet üretmeye başlamışlardır (Pride ve Ferrell, 2000).

Değişen koşullar ve pazarlama stratejileriyle birlikte pazarlama tanımları da değişiklik göstermiştir. Amerikan Pazarlama Birliği 1985 yılında pazarlamayı; "kişisel ve örgütsel amaçlara ulaşmayı sağlayacak değişimi meydana getirebilmek için, mal, hizmet ve fikirlerin geliştirilmesi, fiyatlandırılması, dağıtılması ve tutundurulmasına yönelik bir planlama ve uygulama süreci” olarak yeniden tanımlamıştır (Üner, 2003:15). Bu tanım en çok kabul gören tanım olmuş ve pazarlama ilk kez açık bir şekilde pazarlama karması temelinde tanımlanarak pazarlamanın sınırları çizilmiştir. Buna benzer bir tanım ile pazarlama 1981 yılında Stanton tarafından "mevcut ve potansiyel tüketicilerin, isteklerini tatmin edici mal ve hizmetleri sunmak üzere planlama, fiyatlandırma, dağıtma ve tutundurma amaciyla gerçekleştirilen ve birbirini etkileyen işletme faaliyetleri sistemidir." şeklinde tanımlanmıştır (Alabay, 2010:221).

1990’larda pazarlamada dördüncü dönem olarak adlandırılan postmodern pazarlama dönemi başlamıştır. Bu dönemde, standart ürünlerin yerine kişiye özel seri üretimler geliştirilmiştir. Bu dönem işletmeleri, tüketici odaklı ve kaliteli hizmet anlayışına sahip olmakla birlikte hızla değişen tüketici eğilimlerine ayak uyduran, değişimi takip eden ve bunlara ayak uydurabilecek esnek ve çevik bir alt yapıya sahip olan, niş pazarları ve ilişkisel deneyimi önemseyen bir pazarlama anlayışına sahip olma zorunluluğunda bırakmıştır (Fırat, 1992). İlerleyen süreçte müşteriler işletmenin paydaşı olarak görülmeye başlanmış, müşterilerle işbirliği halinde uzun vadeli sadakat ilişkisi sağlayacak değer üretimi içerisinde bulunmak işletmelerin temel stratejisi haline gelmiştir. Bu anlayış postmodern dönem içerisinde müşteri sadakati üzerine kurulu pazarlama anlayışını geliştirmiştir. Müşteri söylemleri ile işletmenin müşteriler hakkındaki bildiklerini esas alarak her bir müşteriyle bireysel etkileşimde bulunan ilişkisel pazarlamanın bir uygulaması niteliğindeki müşteri ilişkileri yönetimi de bu dönemde önem kazanmaya başlamıştır (Peppers ve Rogers, 1999:67). Postmodern pazarlama anlayışı pazarlama tanımları üzerinde de etkisini göstermiş bu doğrultuda AMA (Amerikan Pazarlama Birliği) tarafindan 2004 ve 2007 yıllarında pazarlama yeniden tanımlanmıştır. 2004 yılında yapılan tanıma göre pazarlama; "müşteriler için değer üretmeyi, bunu tanıtma ve sunmayı; örgütün ve paydaşlarının yararına olarak müşteri ilişkilerini yönetmeyi hedefleyen bir fonksiyon ve süreçler dizisi" olarak tanımlanmış, 2007 yılında ise pazarlama tanımı yeniden 
güncellenerek; "müşteriler, alıcılar, paydaşlar ve toplumun bütünü için değer ifade eden önerilerin geliştirilmesi, iletişimi, ulaştırılması ve değişimi için bir faaliyet, bir dizi kurum ve süreç" olarak tanımlanmıştır (Altunışık, Özdemir ve Torlak, 2014). Kotler ve arkadaşları da pazarlamayı en genel çerçevesiyle şu şekilde tanımlamıştır; "Pazarlama firmaların, hangi malların veya hizmetlerin müşterilerinin ilgisini çekeceğini tayin etmeleri ve satışlar, iletişim ve işletme idaresi geliştirmeleri için stratejileri belirlemeleri sürecidir" (Bulunmaz, 2016:353). 2004 yılından itibaren yapılan tanımlarla birlikte pazarlama tanımlarında paradigma kaymasının yaşandığ 1 görülmektedir. Önceki tanımlarda görülen "kişisel ve örgütsel" ifadesi yerini "paydaşların menfaatine, "mal, hizmet ve fikirler" ise yerini değer üretme anlayışına bırakmıştır. Tanımlarda yer alan "bir dizi süreç" ifadesi ise pazarlamanın tek bir faaliyetten oluşmadığını, bir çok faaliyetin bileşimi olduğunu göstermektedir. Pazarlama karması paradigması yerini ilişkisel pazarlama paradigmasına bırakmış ve 2000'li yıllarla birlikte ilişkisel pazarlama literatürdeki popülaritesini en üst düzeye çıkarmıştır. Postmodern pazarlama anlayış1 ile birlikte pazarlamanın temel amacı; daha iyi nedenler üreterek müşteriye satış yapmak yerine, tüketicileri bir paydaş olarak görüp kişiye özel faaliyetlerle müşteri sadakati oluşturmak ve müşterileri marka/işletmenin reklam unsuru haline getirmek için daha iyi nedenler sunmak olarak değişme göstermiştir. Bu yeni değişimle birlikte denilebilir ki, müşteri işletme yönetiminin en üst kademesinde yer almaya başlamıştır (Odabaşı, 2000:184).

\section{POSTMODERNIZM VE POSTMODERN PAZARLAMA FAALIYETLERİ}

20. yüzyıl, toplumlarda, teknolojide ve kavramsal şekiller arasında büyük değişimlerin yaşandığı bir dönem olmuştur. Bu durum da relativist düşüncenin verimli bir şekilde gelişmesine zemin hazırlamıştır. Bunun sonucu olarak da son 30-40 yılda relativist düşünce önemli gelişmeler katetmiştir (Muncy ve Fisk, 1987).

Bunlarla birlikte, relativizmin düşünce tarzı pazarlama biliminde postmodernist bir pazarlama anlayışının ortaya çıkmasına sebep olmuştur. Postmodernizmi gündeme getiren ve etkileri sürekli artan relativist düşüncenin Einstein' in izafiyet teorisi; doğada hiçbir şeyin yok olmadığı ve sadece sürekli değişimin var olduğu, enerjinin maddeye ve maddenin de enerjiye dönüşebileceği düşüncesiyle birlikte düşünüldüğünde de relativist düşünce çağının temelinde 'sürekli değişim' olduğu ortaya çıkmaktadır. Çünkü doğada ve çevremizde hiçbir olgu statik değil aksine sürekli değişim içerisindedir (Ecer ve Canıtez, 2004).

Postmodernizmin özündeki ayırt edici özelliği onun belirli kalıplara sıkıştırılmasına müsaade etmemiş ve postmodernizmin tam olarak ne olduğu konusunda fikir birliği oluşmamıştır (Erdem, 2017:255). Bir görüşe göre kişiselleştirme sürecinin gerçekleştirilmesi olarak ifade edilirken diğer bir görüşe göre postmodernizm sosyalleşme hareketinin başlangıç noktası olarak görülmüştür (Özbölük, 2015:3). Postmodernizmin felsefesi, sosyal hayatın her türlü realist görüşünü ve sosyal hayata dair realist bir bilgiye ulaşılabileceği varsayımını reddetmesidir. $\mathrm{Bu}$ açıdan yeni bir epistemolojik duruş sergilemektedir (Scherer, 2008). Postmodernizm ileri sanayi toplumlarına ilişkin süreçle ilgili değişime dayalı bir kavram olarak karşımıza çıkmaktadır. Bu açıdan postmodernizm; sanayi devrimiyle ortaya konulan değişikliklerin hızla artması sonucunda meydana gelen ve modernizme karşı gelişen tepki hareketidir. Bu tepki, temelde teknolojik ve bilimsel gelişmelerin insanın düşünce şeklinin yapılanmasında etkili olmasına karşıdır ve iletişim odaklıdır. Bu anlamda postmodernizm soyutsaldır denilebilir (Ecer ve Canitez, 2004).

Postmodernizm; tüketicilerle iletişimin ön planda olduğu ve teknolojinin egemen olduğu toplumun konumunun incelendiği modernist anlayışı eleştiren bir teoridir. Postmodernizm dönemi, teknolojinin büyük ölçüde geliştiği ve üretimin sınırsız hale geldiği bir dönemdir. Buna göre postmodernizmin özellikleri kısaca şöyle özetlenebilir (Berkdemir, 2009):

- Genel geçer önermeleri reddeder.

- Farklılıklar ve çeşitlilikler vurgulanır ve benimsenir.

- Hakikat, gerçeklik, doğruluk gibi kavramları ve bu anlayışları tartışır. Gerçeği yorumlar.

- Mutlak değer anlayışı yerine yoruma açık olan seçeneklerle karşı karşıya gelmekten çekinmez.

- Belli bir zamana veya kalıba göre sözcükler kullanmak yerine gerçekliği kendi özerkliği içinde anlamaya çalışır.

- Tek ve mutlak doğrunun hakimiyetine karşıdır. Önemli olan hakikatin ne olduğu değil nasıl oluştuğudur.

Yukarıdaki özellikler dikkate alındığında göz önünde bulundurulması gereken husus teorik olarak postmodernizmin göstergelerinin bir konsepti değil bir eleştiriyi doğurduğudur (Erdem, 2017:256).

Modernizmden postmodernizme geçiş, önemli kültürel değişikliklerin ve teknolojideki hızlı gelişmelerin bir sonucu olarak karşımıza çıkmaktadır. Baskın dijital ve elektronik işlemler kitleler halinde kültürlerin sürekli 
olarak değişmesine neden olmaktadır. Bilgi iletişim teknolojilerindeki gelişmelerin toplumsal ve ekonomik etkileri farklı insan tutum ve davranışlarını ortaya çıkarmıştır (Erdem, 2017:257). Bununla birlikte postmodernizm, sadece modernizm yaklaşımının bir eleştirisi olarak değil, aynı zamanda kalıplara sıkıştırılamayan ve sembollere daha fazla odaklanmak istemeyen bireyleri vurgulayan bir yaklaşım olarak tanımlanmaktadır (Celep, 2019:294).

1950 ve 1970 'li y1llar arasında ortaya atılan teoriler çeşitli yazarlar tarafından tartışılmaya başlanmış, 1980'li yıllara gelindiğinde postmodern eğilimler pazarlama disiplini ve felsefesi üzerinde önemli değişiklikler meydana getirmiştir. Özellikle iletişim teknolojilerindeki hızlı ilerlemeler, ülkeler ve pazarlar arasındaki engelleri en aza indirmiştir. Postmodernizm, hayatın her alanında olduğu gibi tüketim kalıpları ve hayat tarzlarında da etkili olmuştur. Modern pazarlamanın, bilinçli satın alma iradesine sahip aydınlanmış tüketici, tanımı postmodernizmle birlikte değişmiştir. Modern pazarlamada olduğu gibi istikrarlı bir tüketici grubuna güven duymak yerini, sürekli karar değiştirebilen, marka sadakati düşük, anlık satın almalar gerçekleştirebilen, rasyonel düşünceye değil alışveriş deneyimine önem veren bir tüketici profilini takip etmeye bırakmıştır. İnsanlar, birey olarak farklı davranışlar içerisine girmişler; anlık mutluluğu kovalayan, anında tatmin edilmeyi talep eden ve bunu ertelemeyen, gelecek adına bugünden vazgeçmeyen, içerikten çok biçimi önemseyen, tüketime hazır bir tüketici profili oluşturmuşlardır (Berkdemir, 2009). Bu çerçevede tüketiciler birbirlerine benzeyen ürünleri kitlelerden farklılık oluşturacak şekilde küçük farklılıklarla talep etmekte, sıradanlık yerine kendine özgülüğü öne çıkarmakta ve buna uygun ürün farklılıkları istemektedir. Bu durum pazar bölümlemeden parçalanmış daha mikro pazarların tanımlanması ve daha küçük ölçeklerde mal ve hizmetlerin tasarlanması ve pazara sunulmasına yol açmaktadır. Kitlesel üretim yerine küçük gruplara ve hatta kişilere özgü tasarım ve üretim pazarlamanın kaçınamayacağı bir durum haline gelmiştir. Dolayısıyla pazarlama stratejilerinde ürün ve pazarın özelliklerine göre kişiselleştirme ya da kişiye göreleştirilmiş ürünler ön plana çıkmıştır. Tüketiciler satın aldıkları ürünler yanında satın alma öncesi, esnası ve sonrasında kendilerine sunulan hizmetleri dikkate almaktadır. Hatta bunun da ötesine geçilerek günümüz tüketicileri belli ölçüde postmodernist eğilimlerin de etkisiyle mal ve hizmetleri tercih ederlerken yaşadıkları deneyimlere göre satın almalarını gerçekleştirmektedirler (Torlak ve Altunışık, 2012).

Bu gelişmeler; postmodern kültürün ekonomi, psikoloji, sosyoloji gibi alanlarda oluşturduğu etki gibi pazarlama alanında da dış çevreden başlayarak birebir pazarlamaya kadar yeni değişimlerin yaşanmasına yol açmıştır (Keskin ve Memiş, 2011:193). Postmodern pazarlama hali hazırdaki pazarlama kavramlarına alternatif bir yol sağlamamakla birlikte mevcut anlayış veya fikirlerin yanlışlığı konusunda bizi bilgilendirmektedir. Bununla birlikte postmodernizm uygulamada pazarlama ile ilgili yeni ve karmaşık konuların ortaya çıkmasına yol açmıştır (Erdem, 2017:256).

Fırat ve Dholakia (2006:133) bir tiyatro metaforu kullanarak modernden postmoderne doğru giden pazarlamadaki yönelimi açıklamaya çalışmışlardır. Buna göre, sahne ekipmanları, aktörler, yönetmenler ve sanatçılar belirlenen iş ve pazarlama sektörlerinin boyutlarını, tiyatro izleyicileri ise pazarı ve piyasayı tanımlamaktadır. Modern pazarlamaya göre sahnedeki öğeler yönetmen tarafından koordine edilmekte ancak seyirciler performansa dahil edilmeyerek bağımsız bir unsur olarak ele alınmaktadır. Buna karşın postmodern pazarlama; seyircileri pasif bir unsur olarak görmeyerek onları performansa dahil etmeye, sahne unsurlarıla etkileşim halinde olmaya ve ortaya çıkan sonuca ortak etmeye çalışmaktadır. Ayrıca seyirciler sadece sahne unsurlarıyla değil deneyim süreci boyunca diğer seyircilerle (potansiyel ve mevcut müşteriler) de etkileşim halindedirler. Bu da deneyimlerin paylaşılmasını sağlayan bir mekanizmayı oluşturmakta ve insanlara hayatlarını etkileyecek unsurlara müdahil olmalarının yolunu açmaktadır. Normalden farklı olarak, hayal gücü yüksek ve üretken olan post-modern tüketiciler, sembol ve imgeleri hem üretmekte hem tüketmektedir (Erdem, 2017:258).

Postmodern pazarlama alanında, tüketici istek ve beklentilerinde öncelikler değişmekte postmodern tüketici olarak adlandırılan yeni bir tüketici profili ortaya çıkmaktadır. Bu tüketiciler işlevsellikten ziyade ürün veya hizmetten edinebileceği sembolik değerlere ve duygusal tatmine daha fazla önem vermektedirler (Celep, 2019:294). Varinli (2008)'ye göre postmodern tüketici dokuz farklı özelliğe sahiptir; buna göre postmodern tüketici alışveriş yapmayı sever, seçici davranır, iletişim ve etkileşime önem verir, karakter keşfedicidir, eylemcidir, haz arayıcıdır, mağdurdur, isyankardır ve yurttaştır. Postmodern pazarlama da; açıklık/hoşgörü, üstgerçeklik, anın sürekliliği, zıtlıkların birlikteliği-adanmışlı̆ıı kaybı, öznenin merkeziliğini kaybetmesi, üretim ile tüketimin yer değiştirmesi, stil ve biçime önem verme, kaos ve düzensizliğin kabulü gibi sekiz faklı özelliğe sahiptir (Berkdemir, 2009).

Ecer ve Canıtez (2004)'e göre postmodernist yaklaşımla birlikte pazarlama anlayışının temel ilkeleri de aşağıdaki gibi şekillenmiştir: 


\section{- Müşteri, Toplum ve Çevre Odaklılık}

Modern pazarlama anlayışından farklı olarak postmodern pazarlama anlayışı hareket noktası olarak müşteri odaklılığın yanına toplum ve çevre değişkenlerini de eklemiştir (İslamoğlu, 2000:9). Yeni anlayışa göre sadece tüketicinin tatmin edilmesi yeterli görülmemekte, tüketiciyle birlikte toplumun ve çevrenin de tatmin edilmesi gerekmektedir. Tüketiciye yönelik tutumun yanında toplum ve çevreye yönelik tutum da sergilemek zorunda kalan işletmeler pazarlama uygulamalarında hızla değişikliklere gitmişlerdir. Örneğin; Wal-Mart çevreye zarar vermeyen ürünlerini etiketlemiş, $P \& G$ ile Lever Brothers ürettikleri deterjanları daha yoğun konsantre üreterek daha küçük plastik ambalajlar kullanmış ve McDonald's ürünlerinin ambalajlarında plastik ve türevi maddeleri kullanmayı terk etmiştir.

\section{- Bütünleştirilmiş Pazarlama}

Modern pazarlama anlayışından farklı olarak postmodern pazarlama anlayışı hareket noktası olarak müşteri odaklılığın yanına toplum ve çevre değişkenlerini de eklemiştir (İslamoğlu, 2000:9). Yeni anlayışa göre sadece tüketicinin tatmin edilmesi yeterli görülmemekte, tüketiciyle birlikte toplumun ve çevrenin de tatmin edilmesi gerekmektedir. Tüketiciye yönelik tutumun yanında toplum ve çevreye yönelik tutum da sergilemek zorunda kalan işletmeler pazarlama uygulamalarında hızla değişikliklere gitmişlerdir. Örneğin; Wal-Mart çevreye zarar vermeyen ürünlerini etiketlemiş, $P \& G$ ile Lever Brothers ürettikleri deterjanları daha yoğun konsantre üreterek daha küçük plastik ambalajlar kullanmış ve McDonald's ürünlerinin ambalajlarında plastik ve türevi maddeleri kullanmayı terk etmişsir.

Postmodern pazarlama anlayışı bütünleştirilmiş pazarlama çabalarını temel ilke olarak dikkate almaktadır. Bütünleştirilmiş pazarlama faaliyetlerinde ise; pazarlama fonksiyonunun kendi içerisinde koordineli bir şekilde çalışması ve bütünleştirilmesi, pazarlama fonksiyonunun diğer işletme fonksiyonları ile belirli bir düzen içerisinde çalışması ve bütünleştirilmesi, pazarlama fonksiyonunun işletmenin ulusal ve uluslararası dış çevresiyle koordine edilmesi ve bütünleştirilmesi, pazarlamaya yönelik iletişim araçlarının tam olarak bütünleştirilmesi ve ahenk içerisinde çalışmasının sağlanması amaçlanmaktadır.

Postmodern pazarlama yaklaşımında göre pazarlama faaliyetlerinin bütünleştirilmesi iletişim temeline dayanmaktadır. İdeal bir bütünleşme için ise pazarlamaya yönelik iletişim unsurlarının tam bir uyum içerisinde faaliyet göstermesi gerekmektedir. Postmodern pazarlama yaklaşımında işletmenin temel amacı müşteriyi, toplumu ve çevreyi tatmin ederek uzun vadede işletmenin varlıklarını artırmak olmuştur. Burada uzun dönemde işletmenin karının ve karlılığının artırılması yanında, müşteri portföyünü genişletmesi, çevreye dost teknolojilere sahip olmas1, toplumun sağlı̆̆ını tehdit etmeden üretim yapması ve iyi bir imaja sahip olması gibi faktörler de dikkate alınmaktadır. Bunlarla birlikte postmodern pazarlama yaklaşımı mal, hizmet veya fikirlerin müşteriye arz edilmesini, değer oluşturma ve oluşturulan değeri müsşteri sunma olarak algılamaktadır. Müşterinin üretilen ürüne, ürünle birlikte sunulan hizmete, işletme personeline ve işletmenin imajına yönelik kendisine has beklentileri de oluşmaktadır (Ecer ve Canıtez, 2004).

Postmodern pazarlamanın pazarlama literatüründe yer almasıyla birlikte yeni pazarlama kavram ve uygulamaları da ortaya çıkmıştır. Bu kavramlar kısaca aşağıdaki gibi açıklanabilir:

- Sosyal Pazarlama: Toplumun faydasına yönelik olarak başvurulan pazarlama yöntemleriyle ilgili pazarlama alanının geliştirilmesidir (Clemente, 2002). Sosyal pazarlama anlayışıyla birlikte karşımıza üç temel kavram daha çıkmaktadır. Bunlar; insanlık kavramı, akıllı tüketim kavramı ve çevresel zorunluluklar kavramıdır (Kotler, 2000).

- Yeşil Pazarlama: Çevrenin korunmasına yönelik ürünlerin ve ambalajlarının geliştirilmesi ve tutundurmaya odaklı pazarlama süreçlerinin bu yönde yapılandırılmasıdır (Clemente, 2002). Çünkü günümüzde müşterilerin değişen isteklerine karşı işletmelerin sorumlulukları da güncellenmiştir. Artık müşteriler işletmelerden topluma karşı şeffaf ve hesap verebilir olmasını beklemekte ve karar mekanizmalarını bu doğrultuda çalıştırmaktadır (Kotler, 2000). Yeşil pazarlama, tüketicileri bilgilendirici işaret ve açıklamalara, ürün veya hizmeti sunum aşamasında öncelik verir.

- Gerilla Pazarlama: Gerilla pazarlama, özellikle küçük işletmelerin büyük işletmeler karşısında durabilmeleri için kullanabilecekleri etkili ve çok daha az maliyetle uygulanabilecek bir takım pazarlama uygulamaları olarak ifade edilmektedir (Levinson, 1998:10). Gerilla pazarlama, alışılmışın dışında taktiklerle ve beklenmeyen yerlerde, beklenmeyen zamanlarda yürütülen pazarlama kampanyalarıdır. Gerilla Pazarlamanın amacı işletmelerin kendi mallarına, hizmetlerine, tekliflerine olan ilgiyi zirveye çıkarırken bu uğraş için harcanılan kaynakları, masrafları en aza indirmektir (Kaya, 2010). 
- Niş Pazarlama: Postmodernist akımlar içerisindeki aşırı parçalanma eğilimleri hiç şüphesiz müşterilerin ihtiyaç, istek ve tercihlerinde de aynı derecede parçalanmalara neden olmaktadır. Niş pazarlama, homojen ve küçük pazar dilimlerinin ayrılması ile buradaki müşteri gruplarının ihtiyaç, istek ve tercihlerinin daha iyi karşılanması amacını taşımaktadır (Ecer ve Canıtez, 2004).

- Küresel Müşteri: Postmodern pazarlama koşulları içerisinde mevcut ve potansiyel müşterilerin nitelikleri de değişmiştir. Bu nedenle postmodern pazarlama uygulamaları içerisinde müşterilere yönelik olarak düşüncelerin küresel, uygulamaların yerel olması kaçınılmaz hale gelmiştir (Ecer ve Canıtez, 2004).

- Sürekli Yenilik: Postmodern felsefenin temelinde bulunan sürekli değişim, pazarlamada da sürekli yenilik eğilimini ortaya çıkarmıştır. Bu eğilim sayesinde işletmeler çeşitli stratejik silahlara sahip olurlarken diğer yönden stratejik pazarlama kararlarında da özgün avantajlara kavuşmaktadırlar (Ecer ve Canıtez, 2004).

- Etkileşimli Pazarlama: Etkileşimli Pazarlama, kişilerin bir pazarlama mesajını diğer insanlara aktarmalarını teşvik eden ve bu sayede mesajın yayılmasını sağlayan stratejiyi tanımlanmaktadır (Helm, 2000:158). Etkileşimli Pazarlama, firmaların mal ve hizmetleri hakkında bir fisıltı veya söylenti oluşturmanın en etkili ve maliyeti en az yöntemlerinden biridir.

- Retro Pazarlama: Postmodern bakış açısı, bugünü yaşamakla birlikte geçmiş ile geleceğin bağlarının koparılmamasını ön görmektedir. Son yıllarda yeni bir pazarlama kavramı olarak ortaya çıkan Retro pazarlama ise bu yönüyle postmodern pazarlamanın bu ihtiyacına cevap verir niteliktedir. Retro pazarlama, bir önceki tarihsel döneme ait ürün veya hizmetin canlandırılarak veya yeniden başlatılarak tüketiciler nezdinde o dönemin yeniden yaşanabilmesini sağlamayı amaçlamaktadır. Geçmiş ve geleceği birlikte deneyimleme isteği, geleneksel ve tüketiciler nezdinde kutsal olanın yeniden keşfine, elde edilmeye çalışılmasına ve kullanılmasına neden olmaktadır. Bu haliyle Retro pazarlama, önceki döneme ait koku, müzik, film, kitap vb. çağrışımlar üreterek tüketiciler açısından farklı bir pazarlama hizmeti sunmaktadır (Keskin ve Memiş, 2011:191).

- Illişkisel Pazarlama: Postmodern pazarlama müşterilerini işletmenin bir parçası olarak görmekte ve ürün veya hizmetin ortaya çıkmasında müşterinin de söz sahibi olduğu kişiye özel bir anlayışı geliştirmektedir. Bu anlayışla; birebir pazarlama, mikro pazarlama, veri tabanlı pazarlama gibi kavramlarla da nitelendirilen ilişkisel pazarlamada temel amaç müşteriyi türdeş bölümlere ayırmak yerine müşteri ile bireysel ilişki kurmak ve bu ilişkiyi sürdürülebilir hale getirmektir. Bu doğrultuda bireysel kimlikleri tanımlanan müşterileri gruplarının ihtiyaçlarına duyarlı davranarak onlara hitap eden ve ihtiyaçların tatminine yönelen bireyselleştirilmiş bir pazarlama yaklaşımıdır (Berkdemir, 2009:143).

\section{SONUÇ}

Her şeyin ölçüsü insandır, temelinde göreceliği baz alan relativizme göre dünyada hiçbir şey insanoğlunun duygularından ve algılamalarından bağımsız olarak yorumlanamaz. Relativist düşünce yapısına göre adlandırmalar, toplumdan topluma hatta insandan insana farklı şekillerde anlamlandırılabilir. Sabit bir gerçekliğin olmadığını, gerçekliğin toplum, insan ve zamana göre sürekli değişkenlik arz ettiğini savunan relativist düşüncenin temeli de bundan dolayı sürekli değişime dayanmaktadır. Çünkü relativizm, doğadaki hiçbir olgunun durağan olmadığını savunmuş ve bu yaklaşım doğrultusunda pazarlama biliminin epistemolojik temelde yeniden yapılandırılmasını sağlamıştır.

Relativist düşünce yapısının etkisiyle gelişen postmodern pazarlama anlayışıyla pazarlama bilimi, günümüzde geleneksel metotların kullanıldığı dönemleri çoktan aşmış ve yepyeni boyutlara ulaşmıştır. Bu haliyle pazarlama ve pazarlama iletişimi dünyanın en hızlı değişen sektörleri olarak kabul edildiğinde sürecin bu şekilde devam edeceği ve sürekli değişimin kaçınılmaz bir sonuç olacağı öngörülebilmektedir.

\section{KAYNAKÇA}

Alabay, N. M. (2010), “Geleneksel Pazarlamadan Yeni Pazarlama Yaklaşımlarına Geçiş Süreci”, Süleyman Demirel Üniversitesi İktisadi ve İdari Bilimler Fakültesi Dergisi, 15(2), 213-235.

Altunışık, R., Özdemir, Ş. ve Torlak, Ö. (2014), Pazarlama İlkeleri ve Yönetimi, Beta Yayınevi, İstanbul.

Bayuk, N. (2005), “Global Çağda Müşteri ve Pazarlama Anlayışları”, Pazarlama Dünyası, 5, 30-35.

Berkdemir, Ö. G. (2009), "Postmodern Pazarlama Sürecinin İşleyişi ve Sistemin Yapılandırılması", Yayımlanmamış Yüksek Lisans Tezi, Namık Kemal Üniversitesi Fen Bilimleri Enstitüsü.Tekirdağ.

Boghossian, P. (2006), Truth and Realism 'What is Relativism?', (Ed. P. Greenough ve M. P. Lynch), Oxford Universty Press. 
ÖZ, Murat; KAMACI, Kemal - Relativizm ve Pazarlama Bilimine Etkileri (Relativism and Its Effects on Marketing Science)

Bozkurt, İ. (2014), İletişim Odaklı Pazarlama (Tüketiciden Müşseri Yaratmak), MediaCat Kitapları.

Bulunmaz, B. (2016), “Gelişen Teknolojiyle Birlikte Değişen Pazarlama Yöntemleri ve Dijital Pazarlama”, TRT Akademi, 1(2), 348-365. https://dergipark.org.tr/tr/pub/trta/issue/23620/252060 adresinden erişildi.

Celep, E. (2019), "Postmodern Pazarlama Anlayışı Çerçevesinde Deneyimsel Pazarlamanın Müşteri Memnuniyeti ve Sadakati İle İlişkisinin İncelenmesi”, Selçuk Üniversitesi Sosyal Bilimler Enstitüsü Dergisi, (41), 293-301.

Clemente, M. N. (2002), The marketing glossary: Key terms, concepts and applications, Clemente Books.

Ecer, H. F. ve Canıtez, M. (2004). Uluslarası Pazarlama: Teori ve Uygulamalar, Gazi Kitabevi, Ankara.

Erdem, A. (2017), "Postmodern Pazarlama ve Zitllkların Birlikteliği”, Giresun Üniversitesi İktisadi ve İdari Bilimler Dergisi, 3(6), 254-266.

Ergül, A. (2007), “Grek’lerde Ahlaki Görecelik”, Yayımlanmamış Yüksek Lisans Tezi, Dicle Üniversitesi Sosyal Bilimler Enstitüsü, Diyarbakır.

Firat, A. F. (1992), "Postmodernism and the Marketing Organization”, Journal of Organizational Change Management, 5(1).

Firat, A. F. ve Dholakia, N. (2006), "Theoretical and Philosophical Implications of Postmodern Debates: Some Challenges to Modern Marketing”, Marketing Theory, 6(2), 123-162. doi:10.1177/1470593106063981

Gedik, A. (2020), "Davranış Ekonomisi Ve Tüketici Davranışları Açısından Bir Uygulama”, Sosyal Araştırmalar ve Yönetim Dergisi, (1), 23-40.

Helm, S. (2000), "Viral marketing-establishing customer relationships by word-of-mouse”, Electronic markets, 10(3), 158-161.

Kaya, İ. (2010), Pazarlama Bi’Tanedir, Babıali Kültür Yayıncılığı, İstanbul.

Keskin, H. D. ve Memiş, S. (2011), "Retro Pazarlama ve Pazarlamada Uygulanmasına Yönelik Bazı Örnekler”, Süleyman Demirel Üniversitesi İktisadi ve İdari Bilimler Fakültesi Dergisi, 16(3), 191-202.

Kotler, P. (2000), Pazarlama Yönetimi, (Çev. Nejat Muallimoğlu), Millennium Baskısı, Beta Yayınları, İstanbul.

Levinson, J. C. (1998), Guerrilla marketing: Secrets for making big profits from your small business, Houghton Mifflin Harcourt.

Mucuk, İ. (2001), Pazarlama İlkeleri, Türkmen Kitabevi, İstanbul, 13. Bask1.

Muncy, J. A. ve Fisk, R. P. (1987), “Cognitive relativism and the practice of marketing science”, Journal of Marketing, 51(1), 20-33.

Odabaş1, Y. (2000), Müşteri İliş kileri Yönetimi, Sistem Yayıncılık, İstanbul.

Özbölük, T. (2015), "Postmodernizm Bağlamında Kabilenin Yeniden Keşfi: Postmodern Tüketici Kabileleri”, Hacettepe Üniversitesi Sosyolojik Araştırmalar E-Dergi, 1304-2823.

Peppers, D. ve Rogers, M. (1999), Enterprise One to One, Doubleday, New York.

Peter, J. P. (1992), "Realism or Relativism for Marketing Theory and Research: A Comment on Hunt's "Scientific Realism", Journal of Marketing, 56(2), 72. doi:10.2307/1252043

Pride, W. M. ve Ferrell, O. C. (2000), Marketing: Concepts and Strategies, Houghton Mifflin, Boston.

Scherer, A. G. (2008), "Critical Theory and its Contribution to the Emergence of Critical Management Studies", The Oxford Handbook of Critical Management Studies, Oxford Universty Press, ss. 29-51.

Sommers, M. S. (1998), Fundamentals of Marketing, McGraw-Hill Ryerson.

Taşçıer, F. (2001), “Antikçă̆ Grek Felsefesinde İnsan Felsefesinin Gelişimi ve Kuşkuculuk”, Yayımlanmamış Yüksek Lisans Tezi, Dicle Üniversitesi Sosyal Bilimler Enstitüsü, Diyarbakır.

Tekin, M., Şahin, E. ve Göbenez, Y. (2014), "Postmodern Pazarlama Yaklaşımılyla Modern Pazarlama Yöntemleri: Güncel Şirket Uygulamaları”, Selçuk Üniversitesi Sosyal Bilimler Enstitüsü Dergisi, (Dr. Mehmet Yıldız Özel Sayısı), 225-233. 
Tiltay, M. A. (2013), "Pozitivist Paradigmadan Eleştirel Pazarlama Çalı̧̧malarına Doğru Pazarlama Bilgisindeki Dönüşüm”, 11. Uluslararası Bilgi, Ekonomi ve Yönetim Kongresi, ss. 1-11.

Torlak, Ö. ve Altunışık, R. (2012), Pazarlama Stratejileri - Yönetsel Bir Yaklaşım, Beta Yayınları, İstanbul, 2. Baski.

Üner, M. (2003), “Pazarlama Tanımı Üzerine”, Pi Dergisi, 4(4), 44-57.

Varinli, İ. (2008), Pazarlamada Yeni Yaklaşımlar, Detay Yayıncılık, Ankara. 